\title{
On the Results of the 2009 Struchkov Prize, a Competition for Young Researchers, and the Announcement of the Current (14th) Competition for 2010
}

DOI: $10.1134 / \mathrm{S} 1063774510030284$

The Struchkov Prize has been awarded annually (since 1997) for the best studies in the fields of crystal chemistry or the application of X-ray diffraction for solving chemical problems. Since 2000 the prize has been funded by the international Struchkov Prize Society, which is made up of former students and colleagues of Yu.T. Struchkov. Researchers that are younger than 36 when they submit their documents and are living in the countries of the Commonwealth of Independent States and Baltic states are allowed to take part in the competition. A study is submitted on behalf of one author; and each author can submit only one study. At least one paper on the subject of the study submitted should be published or accepted for publication in a journal where publications are reviewed. The winner is determined by a special Jury, which is formed by the governing body of the X-Ray Diffraction Center from the leading Russian experts in crystal chemistry and X-ray diffraction analysis. The jury's verdict is announced no later than November 1 of that year.

Twelve young researchers from Yekaterinburg, Kazan, Kiev, Minsk, Novosibirsk, Nizhni Novgorod, Rostov-on-Don, St. Petersburg, and Chernogolvka took part in the competition in 2009. The total prize fund for 2009 was 80000 rubles.

The 2009 Struchkov Prize was awarded to Vladislav Yur'evich Komarov, leading engineering technologist at the Laboratory of Clathrate Compounds, Nikolaev Institute of Inorganic Chemistry, Siberian Branch, Russian Academy of Sciences (RAS), for his study "New Features of the Structure of Clathrate Hydrates Which Determine Their Phase Variety: Diffraction Experiment and Simulation."

Seven runner-up prizes for studies held in high regard by the jury were awarded to A.V. Gutov (Kiev, Kiev National University, National Academy of Sciences of Ukraine), O.N. Kazheva (Chernogolvka, Institute of Problems of Chemical Physics, RAS), O.A. Siřdra (St. Petersburg, St. Petersburg State University), E.V. Baranov (Nizhni Novgorod, Institute of Organometallic Chemistry, RAS), Yu.K. Voronina
(Kazan, Institute of Organic and Physical Chemistry, Kazan Scientific Center, RAS), P.A. Slepukhin (Yekaterinburg, Institute of Organic Synthesis, RAS), and V.S. Min'kov (Novosibirsk, Novosibirsk State University). Being awarded a runner-up prize does not exclude the possibility of participation in following competitions.

To take part in the Competition of 2010, one has to present (no later than September 1, 2010) the following documents to the X-Ray Diffraction Center.

(1) A competitor's form, which includes:

(i) complete surname, name, and patronymic;

(ii) name of the study;

(iii) day, month, and year of birth;

(iv) degree and position;

(v) affiliation (in complete form);

(vi) mail address of the institution;

(vii) service telephone;

(viii) fax;

(ix) e-mail address.

(2) An abstract of the study (no more than three pages, with no more than 38 lines (65 signs in a line) per page). The personal contribution of the competitor must be clearly formulated in the abstract.

(3) List of published (or ready for publishing) papers related to the subject of the study submitted.

(4) Xerox copies of all papers (or some of them) from the list in item 3 (at the author's will).

These documents must be sent to

X-Ray Diffraction Center, Nesmeyanov Institute of Elementorganic Compounds, Russian Academy of Sciences, ul. Vavilova 28, Moscow, 119991 Russia or e-mailed (*.doc or *.rtf files) to premiya@xrlab.ineos.ac.ru. Any necessary information can be obtained by telephone (499) 135-93-43 or premiya@xrlab.ineos.ac.ru. 